\title{
Negative Perceptions of Urban Tourism Community in Beijing: Based on Online Comments
}

\author{
Ping $\mathrm{Li}^{1,2}$, Kaiyong Wang ${ }^{1 *}$, Tian Chen ${ }^{1}$, Fuyuan Wang ${ }^{1,2}$ \\ 1. Key Laboratory of Regional Sustainable Development Modeling, Institute of Geographic \\ Sciences and Natural Resources Research, Chinese Academy of Sciences \\ 2. University of Chinese Academy of Sciences \\ *Corresponding Author, Email: wangky@igsnrr.ac.cn
}

Received: Oct 18, 2016; Accepted: Jan 27, 2017

Key Words: Urban Tourism Community, Negative Perception, Online Comments, Content Analysis, Beijing

\begin{abstract}
The development of urban tourism community (UTC) will bring new vigor and vitality into the urban sustainable development. There are abundant tourists' comments about personal experience in UTC in online travel communities, which provide good access to the knowledge of negative perceptions of urban tourism community. Based on online comments, this paper used content analysis method to research tourists' negative perceptions about five typical tourism communities in Beijing, whereby the common problems and special problems of UTC were identified. According to the research results, the authors made suggestions to the sustainable development of UTC in Beijing.
\end{abstract}

\section{INTRODUCTION}

As the functions of attracting tourists and creating place identity, destination perceived image is the important source of forming destination competitive advantage in an increasingly tourism competitive environment (Crompton, 1979). Nowadays, more and more tourists want to experience the local community culture, so UTCs become the important component of the urban destination system. The term of UTC refers to an open urban recreation place where both visitors and local residents can freely access and share, and it is usually evolved from a local community. As a cultural and recreational attracts gathering zone, the UTC plays an important role in the decision process of destination choice. Research on the negative perceptions of UTCs' images can provide implications for improving the image of UTC, and optimizing destination marketing management strategy (Chen, C.-C. et al., 2016).

In 1970s, John Hunt began to research on the tourism destination image (Pike, 2002). Then, this field has become one of the hot spots of international tourism research in recent years (Chew \& Jahari, 2014; Echtner \& Ritchie, 1991; Gertner, 2011; Mayo, 1973). Image evaluation is the main topic of image research. The evaluation methods can be divided into three categories: quantitative evaluation, qualitative evaluation, comprehensive evaluation (Liu \& Wang, 2010). The quantitative evaluations mainly include factor analysis, multidimensional scaling analysis, and correspondence 
analysis and so on. Qualitative assessments include content analysis method, picture heuristic method, grounded theory method and so on. The basic idea of quantitative evaluation is to select a series of evaluation attributes, use statistical methods based on quantitative data to measure the destination image. However, the structural evaluation questionnaire will restrict the free expressions of the respondents, and it can hardly capture the comprehensive features of people's perceptual feelings. Therefore, a qualitative evaluation method would be more effective when exploring a new type of destination perceptions, such as the UTC destinations.

The Internet has become a convenient channel for tourists to express their views and impressions about the tourism destination. These comments which reflect the tourists 'perceptions are the important text materials for scholars to study the image (Dwivedi, 2009; Govers \& Go, 2004; Zhou, 2014; Kladou \& Mavragani, 2015). Through the content analysis of tourism brochures, Dilley (1986) revealed that the image of different countries can be divided into four categories: landscape, culture, entertainment, service. Stepchenkova and Morrison (2006) found that the Russian image descriptions on the websites in the U.S. are one-sided through the contrastive analysis of the texton Russia and American travel websites. Choi, Lehto, and Morrison (2007) researched the Macao tourism destination image through the content analysis of comments from the Macao official travel website, the travel agent website and the travel service website and so on. Govers, Go, and Kumar (2007) used the artificial neural network method to analyze seven tourism destination images. Kladou and Mavragani (2015) analyzed the online comments from the website-Trip Advisor to explore the tourism destination image. Hunter (2016) analyzed the online comments and the traditional print media reports to reveal the image of Seoul.

Previous destination image researches focus on the concept, measurement, and the relationship with the tourist behaviors, and the positive perceptions of destinations, while the negative perceptions were under-explored. Positive perceptions reflect the positive factors of attracting tourists, but the negative perceptions can provide insights in improving tourism services, and promoting destination sustainable development.

\section{METHODS}

\section{$2.1 \quad$ Study areas}

Beijing, the capital of the China, is a famous international, historic and cultural city in the world. Rooted on the diverse, profound cultures and highly developed tourism industry, there are many UTCs. In this paper, five typical UTCs were selected as research areas, which are Nanluoguxiang, 798 Art District, Sanlitun, Shichahai, Dashilan. Online comments were collected from websites of Baidu Travel, Ctrip, Qunar, Lvmama, Tongcheng, wthich are 5 major online tourism service providers in China. Among them, Nanluoguxiang is a narrow alley which was built in the Yuan Dynasty. Physically, it is composed by the traditional residential courtyards and fish-bone type roads called 'hutong'. It was elected as one of 25 best recreation places in the world by the US' Time magazine. 798 Art District was a factory, and then transformed into a modern art district. Shichahai is Beijing's largest historic conservation area with open water area. Dashilan is a large commercial district, which has 500 years history. Sanlitun is a 
famous recreation areas known for its exotic atmosphere and bars. There are 77 embassies gathering around the Sanlitun area.

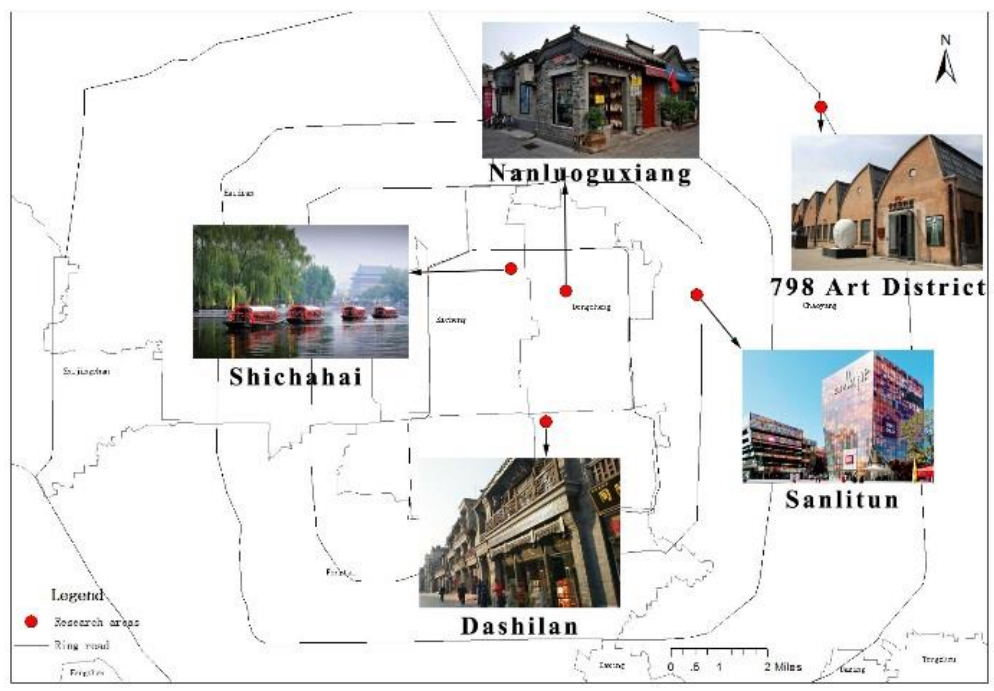

Figure 1.The location of five research areas in Beijing

\subsection{Research data}

After examined the comments from the websites of Baidu Travel, Ctrip, Youduoduo, Trip Advisor, Lvmama, Mafengwo, Tongcheng, we found that only Baidu Travel (A), Ctrip (B), TripAdvisor (C) provided the information of visitors' ratings. All ratings from these three websites were collected and then analyzed by using a descriptive statistics method. Visitors' ratings for very poor, poor, general, good, very good, were scored as $1,2,3,4,5$ respectively.

Table 1. The number of different online platforms' comments

\begin{tabular}{|c|c|c|c|c|c|c|c|c|c|c|c|c|c|c|c|}
\hline \multirow{2}{*}{$\begin{array}{l}\text { Research } \\
\text { areas }\end{array}$} & \multicolumn{3}{|c|}{ Very good } & \multicolumn{3}{|c|}{ Good } & \multicolumn{3}{|c|}{ General } & \multicolumn{3}{|c|}{ Poor } & \multicolumn{3}{|c|}{ Very poor } \\
\hline & A & B & $\mathrm{C}$ & A & B & $\mathrm{C}$ & A & $\mathrm{B}$ & $\mathrm{C}$ & A & B & $\mathrm{C}$ & A & B & $\mathrm{C}$ \\
\hline Nanluoguxi & 161 & 87 & 24 & 142 & 55 & 26 & 40 & 15 & 6 & 6 & 2 & 6 & 3 & 1 & 4 \\
\hline ang & 3 & 3 & 4 & 4 & 9 & 1 & 1 & 8 & 2 & 4 & 0 & & 0 & 4 & \\
\hline 798 Art & 134 & 35 & 27 & 105 & 22 & 24 & 31 & 64 & 3 & 3 & 1 & 4 & 2 & 3 & 3 \\
\hline District & 3 & 4 & 6 & 8 & 0 & 5 & 7 & & 5 & 7 & & & 4 & & \\
\hline \multirow[t]{2}{*}{ Shichahai } & 471 & 55 & 32 & 486 & 33 & 25 & 88 & 67 & 5 & 1 & 1 & 0 & 0 & 7 & 0 \\
\hline & & 3 & & & 6 & & & & & 4 & 5 & & & & \\
\hline \multirow[t]{2}{*}{ Dashilan } & 285 & 26 & 26 & 382 & 18 & 30 & 13 & 65 & 1 & 4 & 9 & 2 & 7 & 5 & 0 \\
\hline & & 4 & & & 1 & & 8 & & 4 & & & & & & \\
\hline \multirow[t]{2}{*}{ Sanlitun } & 500 & 13 & 44 & 456 & 75 & 46 & 14 & 24 & 1 & 2 & 2 & 2 & 8 & 3 & 3 \\
\hline & & 8 & & & & & 0 & & 4 & 6 & & & & & \\
\hline
\end{tabular}

(Data as of on October 19, 2016; A stands for Baidu Travel, B stands for Ctrip, C stands for

Trip Advisor)

Table 2. The total amount of the five study areas

\begin{tabular}{lllllll}
\hline Research areas & $\begin{array}{l}\text { Very good } \\
(5 \text { points })\end{array}$ & $\begin{array}{l}\text { Good } \\
(4 \text { points })\end{array}$ & $\begin{array}{l}\text { General } \\
(3 \text { points })\end{array}$ & $\begin{array}{l}\text { Poor } \\
(2 \text { points })\end{array}$ & $\begin{array}{l}\text { Very poor } \\
(1 \text { point })\end{array}$ & $\begin{array}{l}\text { The Proportion of less } \\
\text { than3 points }\end{array}$ \\
\hline Nanluoguxiang & 2730 & 2244 & 621 & 90 & 48 & $13 \%$
\end{tabular}




\begin{tabular}{lllllll} 
798 Art District & 1973 & 1523 & 416 & 42 & 30 & $12 \%$ \\
Shichahai & 1056 & 847 & 160 & 29 & 7 & $9 \%$ \\
Dashilan & 575 & 593 & 217 & 15 & 12 & $17 \%$ \\
Sanlitun & 682 & 577 & 178 & 30 & 14 & $15 \%$ \\
\hline
\end{tabular}

According to table 2, the degree of satisfaction of five study areas reviews can be ranked as follows: Shichahai $>798$ Art District > Nanluoguxiang > Sanlitun $>$ Dashilan. The lower degree of tourists'satisfaction in Sanlitun and Dashilan showed that there would beserious problems in these two areas of tourism development.

In order to improve the accuracy of the data, the online comments were filtered following two criteria: (1) the more detailed descriptions were chose first; (2) the recording time is from June 2014 to September 2016.

\subsection{Research method}

The qualitative research method can reveal the overall and psychological impression of tourists, which is not easy to capture in quantitative study (Choi, Lehto, \& Morrison, 2007). Content analysis is one of qualitative research method which aims to extract potential information from textual materials (Chen, Z.-Q. \& Zhang, 2007).

Combining content analysis with the method of comparative analysis, both common negative perceptions and special negative perceptions in five research areas were identified and summarized. Then we proposed solutions and suggestions to improve image of UTCs of Beijing.

Specifically, based on the content analysis of online comments, the contents of negative perceptions of different UTCs were classified into four dimensions: business management, type of operations, infrastructure, and tourism environment. Furthermore, comparative analysis was conducted to compare negative perceptions among these different five UTCs.

\section{$3 \quad$ RESULTS}

\subsection{Common negative perceptions analysis}

(1) Unreasonable price

The "unreasonable price" is one of common negative perceptions in the five research areas. It includes two aspects: first, the food prices (food and drinks, etc.) are too high but the quality and taste of food is unsatisfactory; second, commodity prices are too high but the quality of goods in UTCs is unsatisfactory. Tourists complained that goods prices are much more expensive than the same items in other places. Some comments related to perceptions of "Unreasonable price" were showed as follows:

Comments on food prices:

I do not like it very much ... Cheese is not as good as Sanyuan. It is too expensive.

- 2015.2.14 in Nanluoguxiang

Very noisy, boring $\sim$ the food is not delicious but very expensive

- 2016.3.26 in the 798 Art District

Do remember to ask the price before you buy something in Shichahai's 
drink stalls. A bottle of soda will ask you for 30 yuan.That's a rip-off!

- 2016.8.29 in Shichahai

The price is unimaginable. A bowl of Rice porridge cost me 3 yuan!

- 2016.5.14 in Dashilan

The famous bar street... But you should note that prices are quite high. A meal of 6 people cost nearly two thousand yuan.

Comments on commodity prices:

- 2014.10.2 in Sanlitun

There are a lot of tourists. Things are very expensive. There is nothing special, so I did not buy.

-2016.8.11 inNanluoguxiang

It's very expensive right now!!! It is not worthy of a visit after Dashilan was transformed ...Goods in Dashilan can be bought anywhere else.

- 2015.6.17 in Dashilan

It is a famous bar street in Beijing ...the goods in the business street is very expensive. There are some goods cost ten thousand yuan or more.

- 2016.2.6 in Sanlitun

(2) Over commercialization

It is another kind of negative perceptions in Nanluoguxiang, 798 Art District, Shichahai and Dashilan areas. Visitors can experience the local culture in the four places years ago. But in recent years, over commercialization has made much negative effects on the UTCs' cultural atmosphere, thus influenced tourists' real experience of UTCs' culture. Visitors did not mention the excessive commercialization of Sanlitun. The main reason is that Sanlitun $\mathrm{SOHO}$ itself is a fashionable business center.

It used to feel the style of old Beijing, but now it is over commercialized. Everywhere you look is food and drink.

- 2016.9.8 in Nanluoguxiang

... Now 798 is over commercialized. There is less good exhibitions.

- 2015.10.23 in the 798 Art District

Now the Houhai's is too much like a commercial area. I am not suggesting that you come here to eat or drink. Many shops cheat customers.

- 2015.8.16 in Shichahai

There are too many people in Qianmen Street. It has been over-commercialized.

- 2016.4.5 in Dashilan

(3) "Lack of unique characteristics", "insufficient infrastructure"

They are the common negative perceptions that existed in Nanluoguxiang and 798 Art District. Lack of unique characteristics mainly refers to the store type, the sale of goods, culture and architecture form in UTCs can also be seen in other cities. Immature physical infrastructure refers to that the rest facilities, signs, toilets and other facilities are not enough to meet the needs of tourists.

Lack of unique characteristics:

I'm very disappointed. It is short of local feature. Shopsare similar with the Kuanzhai Alley in Chengdu, but the scenery is not as good as Kuanzhai Alley (in Chengdu city).

- 2016.7.3 in Nanluoguxiang

To be honest, I think many cities imitate the 798 Art District, such as the eastern suburb of memory in Chengdu.But the building in Chengdu is more beautiful than the 798 Art District.

Insufficient infrastructure:

- 2016.4.11 in the 798 Art District

The only drawback is that there is no place to sit. 
- 2015.7.18 in Nanluoguxiang

Signs of Map are not clear. It will be boring if there is no exhibition there...

- 2015.6.13 in the 798 Art District

(4) Cheating customers

It was a common kind of negative perceptions that existed in Shichahai and Dashilan. "Cheating customers" mainly refers to that tourists were charged too much money when they purchase goods or services. The consumption in bar in Shichahai, were usually complained for the higher prices. There existed fraudulent trading while tourists buy souvenirs in Dashilan.

... You should note that the wine may be charged more than the prices marked when you pay your bills. You'd better check the menu.

- 2015.5.29 in Shichahai

When you go shopping in Dashilan, you should prevent yourself from being cheated...

- 2016.6.26in Dashilan

(5) Insecurity

It was a kind of negative perceptions of Nanluoguxiang and Sanlitun. The comments showed that the public security, especially the tourists' financial security in Nanluoguxiang and Sanlitun need to be improved.

Nanluoguxiang..... Many people, of course, people who steal the phone are also more...... People do not have to call the police, because the police are not there, my cell phone is lost after that police actually said that the camera is broken, cannot see the video! So we have to be careful.

- 2015.3.8 in Nanluoguxiang

What a bad place it is...... mobile phone is stolen in the first day at Sanlitun. Be careful of your properties

- 2014.12.4 in Sanlitun

Table 3. The common problems of the five research areas

\begin{tabular}{ll}
\hline Problems & Reported areas \\
\hline Unreasonable price & $\begin{array}{l}\text { Reported by Nanluoguxiang, 798 Art District, Shichahai, } \\
\text { Dashilan, Sanlitun }\end{array}$ \\
Over commercialization & $\begin{array}{l}\text { Reported by Nanluoguxiang, 798 Art District, Shichahai, } \\
\text { Dashilan }\end{array}$ \\
Lack of unique & Reported by Nanluoguxiang, 798 Art District \\
characteristics & \\
Insufficient infrastructure & Reported by Nanluoguxiang, 798 Art District \\
Cheating customers & Reported by Shichahai, Dashilan \\
Insecurity & Reported by Nanluoguxiang, Sanlitun \\
\hline
\end{tabular}

\subsection{Specialnegative perceptions of five UTCs}

There are some special negative perceptions related to the community culture or management in the five UTCs. These special negative perceptions reminded the community to pay attention to their own problems and find suitable solutions to promote the sustainable development of UTC.

(1) Nanluoguxiang

1) Crowded 
Too many visitors in the Nanluoguxiang had negative impacts on the travel experience quality of tourists. Especially during the holidays, large number of tourists has brought high pressure to the tourism community management, also affected the normal life of the residents negatively.

Nanluoguxiang is so crowded. I could not even take out the camera...

$-2015.12 .21$

Many people there ...too crowded.

$-2016.9 .18$

2) Unfriendly residents

Residents' attitudes are not friendly. There are a lot of old natives of Beijing in Nanluoguxiang. Due to the tourism development, some natives had rent out their houses and left the place, and some residents still live here. Residents are not welcomed because they had disturbed residents' normal life.

The old lady who sells Chinese paper cutting is particular unfriendly. $-2014.9 .17$

I have visited so many attractions in Beijing. Nanluoguxiang is the worst one... In particular, the resident's attitude is even worse. We were not allowed to stand beside the door of Courtyard... The tourism quality is really bad. I do not recommend you to visit.

$-2015.3 .22$

(2) 798 Art District:

1) The Lack of unique commodities

798 Art District has strong artistic atmosphere. But some tourists thought that the place lacked unique commodities. Some same goods are sold in a lower price in other places. This phenomenon reduced the degree of tourists' satisfaction with the 798 Art District.

It is puzzling... Things inside are very common ... which are similar with other goods in other tourism spots.

- 2014.6.8

There are various kinds of handicrafts, but online prices will be cheaper...

$-2015.11 .17$

2) Bad traffic conditions

798 Art District locates in the Dashanzi area, about 1.1 kilometers away from the subway station. Tourists can reach the place by buses, but compared with other areas such as Nanluoguxiang, Shichahai, Sanlitun, Dashilan, the traffic is not very convenient. This is one negative factor that influence the tourism development of 798 Art District.

The art district is very large... and traffic is not very convenient.

- 2014.10.1

Walked a long time from the subway station to $798 .$. If you are stranger, you are likely to lose the way.

$-2016.8 .1$

3) The modern art is difficult to be understood

Visitors' comprehension abilities are different, so the perceptions of the art is not the same. The novel Art style the key to attract tourists. The art area will become more popular when the art were presented in a in an understandable way.

So many places are confused. If you can't understand, I suggest you not 
to visit this place.

I can't appreciate art.

(3) Shichahai: Ask for tips by drivers of tricycle

Human "rickshaw" is the traditional vehicle for visitors to experience Beijing's ancient culture. But the market of Human "rickshaw" was usually complained for its lack of management and regulations. Old Beijing Hutong-Sightseeing by Rickshaw provided opportunities to visit the courtyard. However, these services had made a bad impression on the visitors because of the tricycle drivers' behaviors of asking for tips.

I feel very disappointed... we were treated badly because we did not give tips... the tricycle driver should be more professional.

$-2015.8 .12$

Because I didn't give tips, the driver became so rude. And I have not experience the characteristics of Hutong. After I got out of the tricycle, the driver even abused us...

$-2016.7 .10$

(4) Dashilan: the loss of "old Beijing"

As a traditional old commercial district in Beijing, There are a number of old brand shops in Dashilan. But Tourism development resulted in the lost of its cultural identity of "old Beijing". Unsatisfied with the qualities and cultural characteristics of goods, visitors could not feel the atmosphere of old Beijing's marketplace.

No old Beijing features, no characteristics of the commercial street ... Usually nobody, there are too many people during holidays.

It used to be the most characteristic areawith civil life in Beijing ...now it is a non-descript Qianmen street, full of fake antique buildings,and Snacks.

$-2016.8 .3$

(5) Sanlitun: fears of "soliciting"

The numbers of bars within Sanlitun area have been increasing since the late 1990s. But many tourists mentioned their fears of soliciting in the Bar Street. The soliciting would have negative effects on the tourism sustainable development of Sanlitun.

Don't believe those who pull you to those bars! It's hard for you to go out! You would be compelled to spend tens of thousands of yuan before leaving.

Bar Street ...the soliciting in the street is so uncomfortable. It is Very annoying; and very necessary to be regulated.

Table 4 . The personality problems of the five research areas

\begin{tabular}{ll}
\hline Research areas & Problems \\
\hline Nanluoguxiang & The number of tourists is too much \\
\hline
\end{tabular}


Residents' attitudes are not friendly

798 Art District Lack of commodity characteristics

Bad Traffic conditions

Cannot understand the modern art

Shichahai Asking for tips by drivers of tourism tricycle

Dashilan No Beijing taste

Sanlitun "soliciting" in the Bar street

\subsection{Factors analysis of negative perceptions}

Based on the common and special negative perceptions identified above. The study classified the problems in Beijing urban community tourism development into four categories: business management, types of operations, infrastructure, and environmental issues:

(1) Business management problem. It includes unreasonable price, cheating customers, tips and soliciting. Specifically, the commodity prices are too high. And there existed phenomenon like cheating customers, forcing visitors to give tips, soliciting.

(2) Problem on types of operations. Five problems were identified: over commercialization, homogeneity of scenic spots, lack of unique commodities, the puzzling modern art, and the lack of Beijing feature. Types of operations are important parts of urban community tourism development, and it is also one of the main ways for tourists to feel the cultural atmosphere of the community.

(3) Problems about infrastructure. It includes uncompleted infrastructure and bad traffic conditions. The infrastructure in UTC includes the sign, toilet, rest areas and other facilities. The traffic inconvenience is mainly determined by the location of the UTC. Immature Signs, toilets, rest areas and other facilities brought some troubles to tourists. The bad traffic will reduce the number of tourists.

(4) Problems about tourist environmental issues. It includes three problems: insecurity, crowed environment, and unfriendly residents' attitudes. Visitors pursue safe, comfortable, friendly environment. The crowed environment produced negative effects on tourists' feelings. In addition, too much tourists bothered the normal life of the local residents, making residents' attitude more unfriendly.

Overall, among all problems, the business operation is the most obvious, which was accounted for $64 \%$ of the total. Infrastructure and tourist environmental was accounted for $36 \%$. It showed that the management problems are related to the operation of businesses. The environment problems were mainly about Infrastructure and tour environment. 


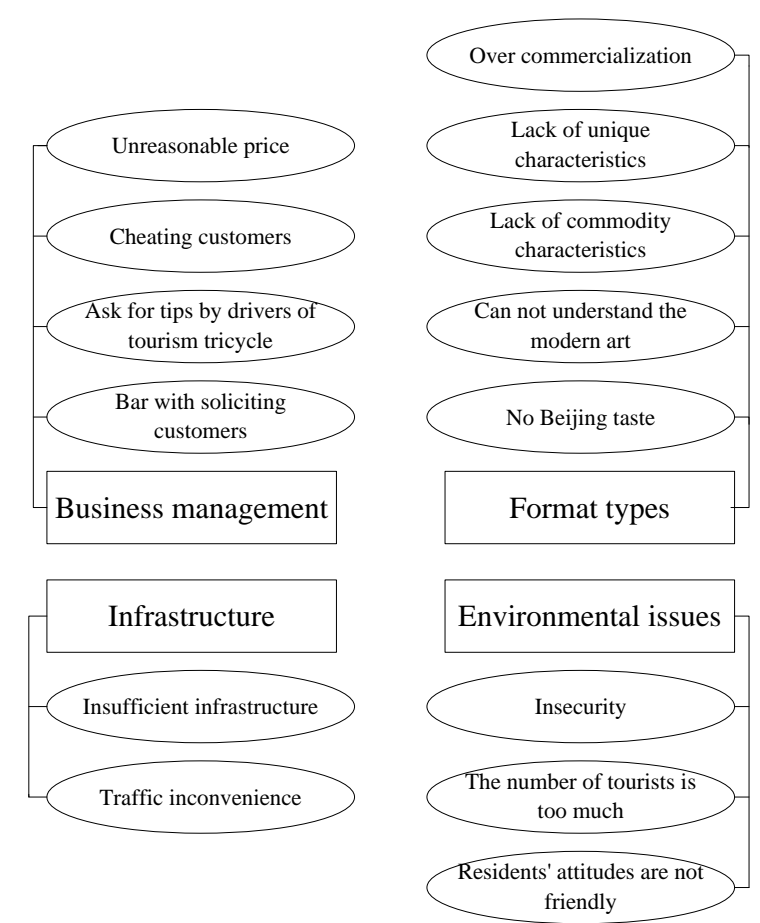

Figure 2. Summary of tourism development problems in the five research areas

\section{CONCLUSIONS AND SUGGESTIONS}

This study conducted a qualitative case study of online negative perceptions of UTC in Beijing. Through the analysis of online comments, problems can be summarized in four categories: business management, format types, infrastructure, and environment issues. In order to solve these problems, three suggestions were put forward as follows.

The community management institutions should be improved to solve the problems. The UTC should make relevant market admission standards of the types of operations to ensure the quality of commodities. Second, the government should create a favorable policy to support the high-quality business operators, and control the price of rents and goods. Third, channels for complaints should be established to supervise the goods and services trade.

Business owners should provide better products with local characteristics and high quality. Second, in terms of tourism services, the service attitudes should be enhanced to avoid the occurrence of using violent or threatening methods to sell goods. Finally, the relationships of businesses operators and residents should be coordinated, to create employment opportunities for local residents and best environment for tourists.

Finally, tourists should be educated to beat the crowds, not to break the local landscapes, culture, and environment and not to disturb normal life of local residents. In the case of being forced to buy, tourists should sue promptly.

\section{REFERENCES}

Chen, C.-C., Lai, Y.-H. R., Petrick, J. F., \& Lin, Y.-H. (2016). "Tourism between Divided Nations: An Examination of Stereotyping on Destination Image". Tourism Management, 
$55,25-36$.

Chen, Z.-Q., \& Zhang, G.-X. (2007). "Study on the Text Mining and Chinese Text Mining Framework [J]". Information Science, (7), 1046-1051.

Chew, E. Y. T., \& Jahari, S. A. (2014). "Destination Image as a Mediator between Perceived Risks and Revisit Intention: A Case of Post-Disaster Japan". Tourism Management, 40, 382-393.

Choi, S., Lehto, X. Y., \& Morrison, A. M. (2007). "Destination Image Representation on the Web: Content Analysis of Macau Travel Related Websites". Tourism Management, 28(1), 118-129.

Crompton, J. L. (1979). "Motivations for Pleasure Vacation". Annals of Tourism research, 6(4), 408-424.

Dilley, R. S. (1986). "Tourist Brochures and Tourist Images". The Canadian Geographer/Le Géographe canadien, 30(1), 59-65.

Dwivedi, M. (2009). "Online Destination Image of India: A Consumer Based Perspective". International Journal of Contemporary Hospitality Management, 21(2), 226-232.

Echtner, C. M., \& Ritchie, J. B. (1991). "The Meaning and Measurement of Destination Image". Journal of tourism studies, 2(2), 2-12.

Gertner, D. (2011). "Unfolding and Configuring Two Decades of Research and Publications on Place Marketing and Place Branding". Place Branding and Public Diplomacy, 7(2), 91-106.

Govers, R., \& Go, F. M. (2004). "Projected Destination Image Online: Website Content Analysis of Pictures and Text". Information Technology \& Tourism, 7(2), 73-89.

Govers, R., Go, F. M., \& Kumar, K. (2007). "Virtual Destination Image a New Measurement Approach". Annals of Tourism Research, 34(4), 977-997.

Hunter, W. C. (2016). "The Social Construction of Tourism Online Destination Image: A Comparative Semiotic Analysis of the Visual Representation of Seoul". Tourism Management, 54, 221-229.

Kladou, S., \& Mavragani, E. (2015). "Assessing Destination Image: An Online Marketing Approach and the Case of Tripadvisor". Journal of Destination Marketing \& Management, 4(3), 187-193.

Liu, G.-H., \& Wang, H.-G. (2010). "Measurement of Tourist Destination Image: Based on the Study of Overseas Literature". Tourism Tribune, (6), 83-87.

Mayo, E. J. (1973). "Regional Images and Regional Travel Behavior". Proceedings of The Travel Research Association Fourth Annual Conference Proceedings, Sun Valley, Idaho, pp. 211-218.

Pike, S. (2002). "Destination Image Analysis—a Review of 142 Papers from 1973 to 2000". Tourism Management, 23(5), 541-549.

Stepchenkova, S., \& Morrison, A. M. (2006). "The Destination Image of Russia: From the Online Induced Perspective". Tourism Management, 27(5), 943-956.

Zhou, L. (2014). "Online Rural Destination Images: Tourism and Rurality". Journal of Destination Marketing \& Management, 3(4), 227-240. 